\title{
Accounting Tourism Development Grants in Hungary
}

\section{Summary}

In recent decades demand for and the supply of sustainable tourism related to national parks have increased. Environment-friendly tourism plays an increasingly significant role in the travel habits of the Hungarian population. Hungary has a lot to offer in eco-tourism. Its nature tourism destinations include national parks, on the one hand, and geographical regions, nature parks and geoparks maintained by voluntary civil society organisations. In order to meet the needs of green tourists, centres and nature trails are created and guided tours are organised. Eco-tourism plays an important role in Hungarian tourism and based on the revenues, expenditures and visitor turnovers in natural parks, its importance is increasing in all areas. Support programmes represent vital financial resources in the development of tourism. Several forms of support are available in Hungary to contribute to improvement in different areas. This is a study of the importance, classification and accounting of tourism development grants.

Journal of Economic Literature (JEL) codes: Q57, O52, Z32

Keywords: ecotourism, European Union grants, accounting

Dr Anita BorzÁn, senior lecturer, Budapest Business School (borzan.anita@unibge.hu), Dr Bernadett Szekeres, lecturer, Eötvös Loránd University (szekeres. bernadett@gti.elte.hu). 


\section{Hungarian Ecotourism in a Nutshell}

"Tourism includes, on the one hand, all the movements and activities beyond people's usual routines in life and work, irrespectively of the specific motives, duration and objectives. On the other hand, tourism is also defined as the combination of financial, technical and institutional conditions and services designed to meet the needs related to such movements and activities" (Lengyel, 2004, p. 79). Based on the trends perceptible in tourism, it can be established that demand for sustainable tourism related to protected natural values has increased significantly.

"Ecotourism comprises environmentally responsible travels and visits to relatively undisturbed areas with the aim of enjoying and appreciating their natural and cultural values, sparing them through the mitigation of the impacts of the visit and through the provision of financial and social benefits to the local population" (IUCN, in: Pannon University, 2008, p. 12). Hungary has a lot to offer in ecotourism: national parks, landscape-protection areas (Chart 1), nature parks, geoparks, visitor centres, nature trails and guided tours.

Chart 1: National parks and landscape-protection areas in Hungary

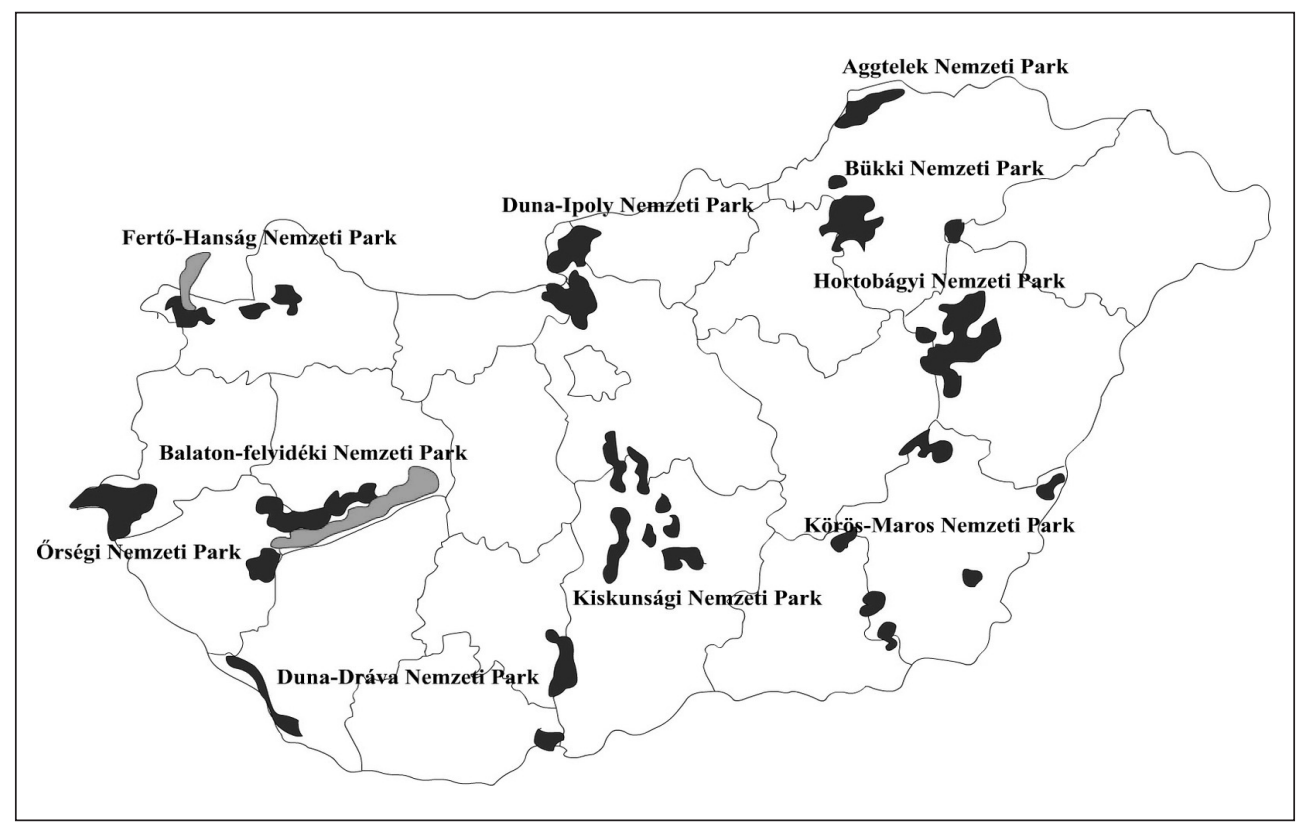

Source: https://tudasbazis.sulinet.hu/hu/termeszettudomanyok/termeszetismeret/ember-a-termeszetben-4osztaly/tajekozodasi-alapismeretek/hazank-termeszeti-ertekei

The international recognition of Hungary's natural values is indicated by the fact that the Hortobágy National Park, the Aggtelek National Park and the Fertô-Hanság Cultural Landscape have all been declared World Heritage Sites. The natural values 
granted the European Diploma of Protected Areas include the Balaton Uplands, the Danube-Ipoly National Park and the Bükk National Park. The European Diploma of Protected Areas is granted by the Council of Europe to areas where outstanding natural, cultural, scientific or aesthetic values are found and excellently managed. The European Diploma of Protected Areas has already been given to the post-volcanic formations of the Tihany Peninsula, the Szénás Mountains as the natural habitat of the Pilis flax, and the Ipolytarnóc Fossils.

A common task in the various areas of ecotourism is raising awareness of the natural values, teaching people to appreciate nature and establishing the conditions of ecotourism. The growing importance of ecotourism is manifest in the increase in visitor turnovers and in incomes. However, this also requires constant improvement, and the areas involved in ecotourism frequently raise the necessary funds from several sources, including grants.

\section{TYPES AND ACGOUNTING OF GRANTS}

Following a conceptual overview of tourism, this study presents the diversity of grants. Mention is made of the large number of different areas where grants are available. As a first step in the research, the legislative background in the EU and in Hungary is described to facilitate understanding the types and accounting of the grants.

\section{The regulation of grants in the $E U$}

As the basic principle of the market functioning in the European Union is the freedom of competition, the Member States are only allowed to grant support and thus influence the functioning of the market for specific purposes. The guiding principles regarding the regulation and control of state support to businesses are laid down at the level of the EU. Development funds play a key role in the budget of the European Union. Cohesion policy includes a large part of the European Union's development grants. The European Union determines the development directions of cohesion policy for seven-year programming periods and assigns resources to them. Part of the development costs are distributed through a decentralised decision-making mechanism, i.e. within the Member States' powers, while another part is allocated by the European Commission in a procedure performed in Brussels.

Hungary receives most EU grants from cohesion policy funds, while the amount of resources provided to the country from central EU programmes is low. The basis of strategic planning for the cohesion policy for the period between 2014 and 2020 includes the Europe 2020 strategy, which determines the objectives of the European Union, providing support for the decentralized EU programmes from the below-mentioned five large funds within the European Structural and Investments Funds (ESF) (Chart 2). 
Chart 2: The five large funds of the European Structural and Investment Funds (ESF)

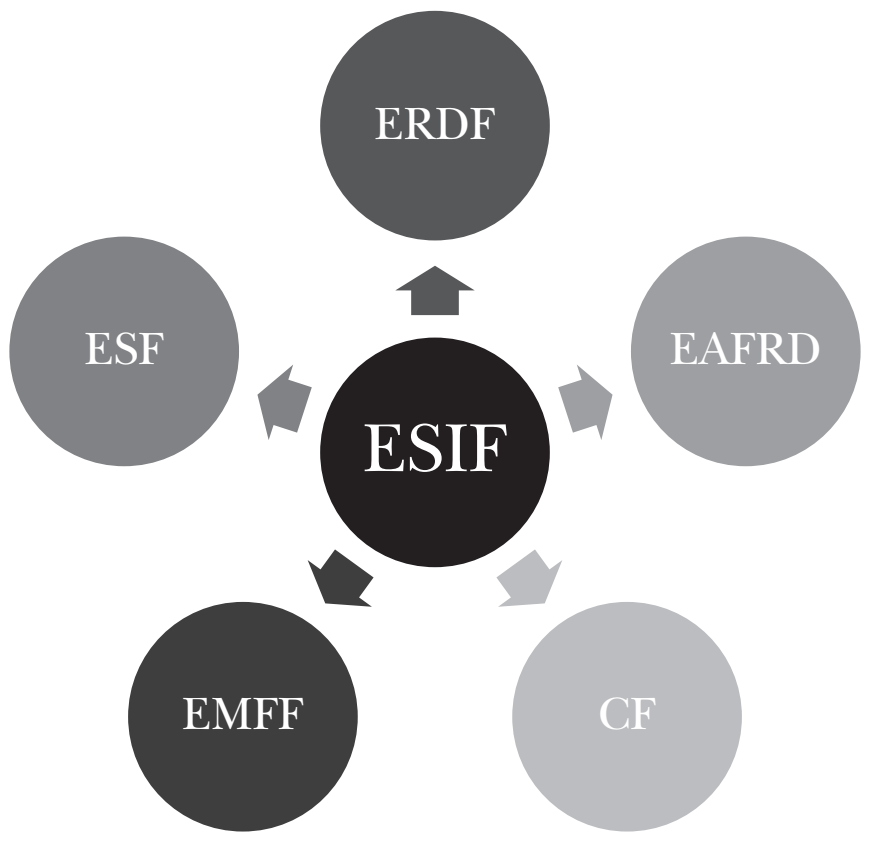

Source: Authors' own

The implementation of the Europe 2020 strategy is promoted by the above-mentioned funds in the following areas:

- European Regional Development Fund (ERDF): Its primary aim is to ease and reduce inequality among regions and, thereby to strengthen economic and social cohesion. Its main priorities are innovation and research, information and communication technology, support for small and medium-sized enterprises, and a low carbondioxide emitting economy.

- European Social Fund (ESF): Its basic principle is improvement in education and employment, including service to people, and its objective is to improve the life for people in multiple difficulties. All the regions can benefit from it. Its main areas comprise promoting mobility, developing employment, raising the level of education and vocational training, fighting poverty and facilitating social inclusion.

- Cohesion Fund (CA): It is primarily aimed at decreasing social and economic inequality between rich and the poorest Member States. Its main fields of application are infrastructure projects and environmental protection.

- European Agricultural Fund for Rural Development (EAFRD): It provides help in managing economic, social and environmental challenges. It has six priorities: knowledge transfer in agriculture and forestry, innovation, support for agriculture technology, competitiveness in agriculture and management of the food supply chain, strengthening and preservation of the ecosystem, and the promotion of resource- 
efficiency, low carbon-dioxide emission, social inclusion and the social development of the countryside.

- European Maritime and Fisheries Fund (EMFF): It is engaged in the preservation of fish stock and the management of fishing fleets, and the economic, social and environmental sustainability of fisheries and aquaculture. Its resources are used for sustainable fisheries, the economic risk management of coastal communities and for the establishment of new jobs.

The guidelines of strategic planning in the EU's cohesion policy for the period between 2014 and 2020 are included in the Common Strategic Framework.

The regional policy of the European Union (Chart 3) has 11 thematic objectives for the programming period of 2014-2020. The investments of the European Regional Development Fund support all the 11 objectives, but the main priorities of the investments are set out in sections 1-4. The main priorities of the European Social Fund are objectives 8-11, but it also supports objectives 1-4. The Cohesion Fund supports the objectives 4-7 and objective 11 .

\section{Chart 3: The 11 thematic objectives of cohesion policy}

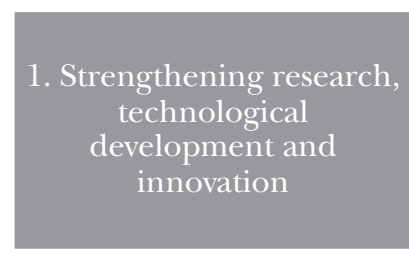

2. Dissemination of, access

to and use of information and communication

technologies and

improving their quality
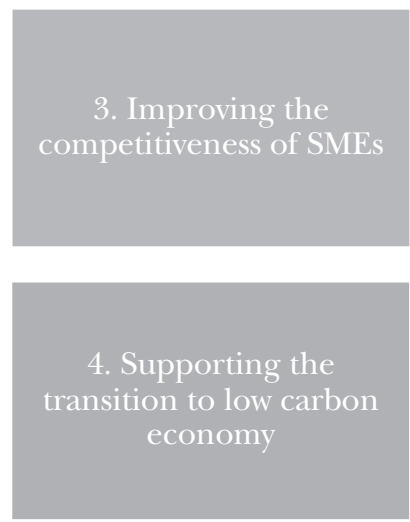

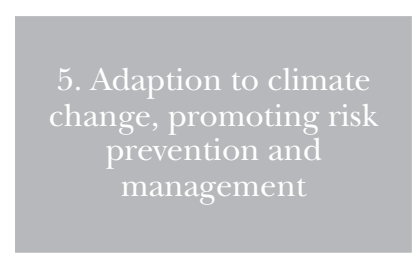

6. Promoting the

efficiency of the

environmental protection

and resource usage
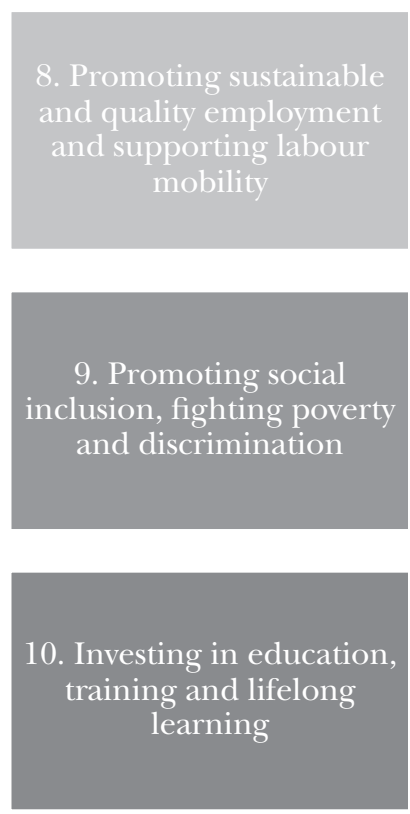

11. Improving the efficiency of public administration

Source: Author's own 


\section{Regulation of grants in Hungary}

The development projects performed in Hungary in the European Union's programming period 2014-2020 were named "Széchenyi 2020", in line with the Europe 2020 strategy. Laws and regulations are included in the national regulation concerning the use of the Structural Funds. The Partnership Agreement (PM) is the highest-level planning document for the allocation of Member States' resources in for the period 2014-2020. It sets Hungary's development needs for the period, the objectives of using the cohesion funds, the operational programmes covering each development area and the allocation of the resources.

In the programming period 2007-2013, 6059 tourism projects were carried out using grant worth HUF 375 billion. Of this amount, HUF 308 billion under the Regional Operational Programmes (ROP).

Chart 4: Breakdown of tourism products by payment (2007-2015)

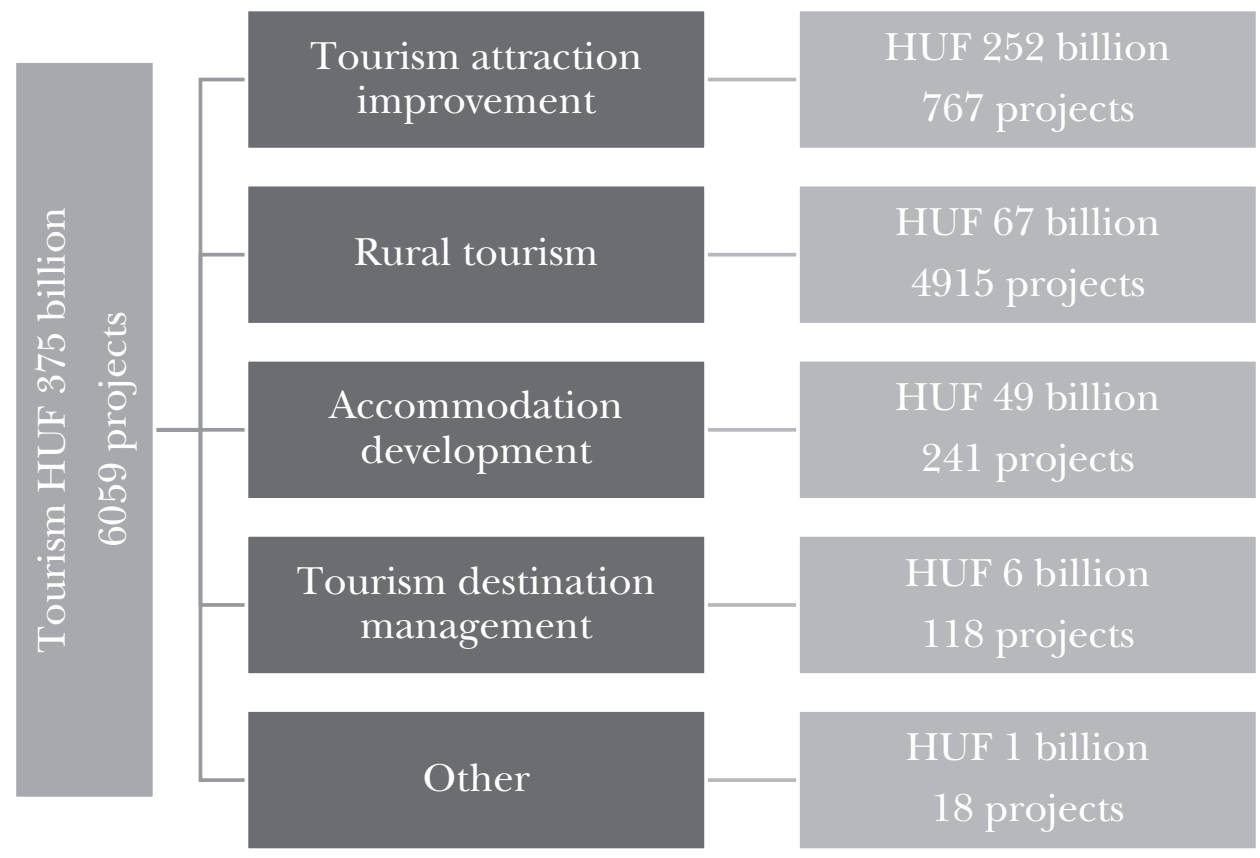

Source: Based on data from KPMG, EMIR and IIER

Table 1 shows tourism attraction developments in a breakdown. The most significant ecotourism projects included the Ecocentre by Lake Tisza and one of the most successful projects in this category, the Zoo in Nyíregyháza.

The overall national development objective of the 2014-2020 programming period is economic growth based on sustainable production with high added value and increasing the employment rate. In order to ensure that developments result in 
Anita Borzán and Bernadett Szekeres: Accounting Tourism Development Grants...

Table 1: Breakdown of tourism products based on payments (2007-2015)

\begin{tabular}{l|l|c}
\hline \multicolumn{1}{c|}{ Tourism sector } & \multicolumn{1}{c|}{ Product } & $\begin{array}{c}\text { Payment, } \\
\text { HUFB }\end{array}$ \\
\hline \multirow{4}{*}{$\begin{array}{l}\text { Tourism attraction } \\
\text { development }\end{array}$} & Heritage tourism & 115 \\
\cline { 2 - 3 } & Health tourism & 49 \\
\cline { 2 - 3 } & Active tourism & 49 \\
\cline { 2 - 3 } & Ecotourism & 22 \\
\cline { 2 - 3 } & Event tourism & 9 \\
\cline { 2 - 3 } & Wine and gastro tourism & 7 \\
\cline { 2 - 3 } & Other & 1 \\
\hline
\end{tabular}

Source: Based on data from KPMG, EMIR and IIER

significant changes, five key national development (support) priorities are interconnected and cover the entire development policy, including rural development objectives and contributions:

1. Improvement in the competitiveness of economic participants and the intensification of their international presence.

2. Increase in employment (through the economy development, employment, education and social inclusion policies, with a view to regional differences).

3. Increase in energy and resource efficiency.

4. Management of challenges related to social inclusion and demography.

5. Implementation of local and regional development projects facilitating economic growth.

According to our opinion, the grants granted by the EU make a significant contribution to Hungary and serve economic and social inclusion. Within the framework of common priorities, the Member States have room to manoeuvre in allocating the available resources to actions and areas where they are really needed.

\section{TOURISM DEVELOPMENT GRANTS IN LIGHT OF THE EU'S THEMATIC OBJECTIVES}

Tourism is one of the significant sectors in Hungary's economy, heavily relying on SME's. It is also a priority area in terms of employment. The ratio of people employed in tourism is considerable even in an international comparison, and tourism businesses act as the predominant employers in villages. Consequently, the tourism attraction development projects are important for employment. Tourism plays a key role in the following thematic objectives:

- The third thematic objective, i.e. improvement in the competitiveness of small and medium-sized enterprises, the agriculture, fisheries and aquaculture, requires several projects in tourism, catering and environmental protection services to support the operational programme for fisheries. Consequently, the Hungarian Fisheries Operational Programme can significantly contribute to the local creation of jobs and 
promote tourism, and the role of fishing tourism can increase not only at fishing lakes but also at other natural waters. The fisheries sector represents a small but labourintensive part in employment in Hungary. However, fisheries can indirectly provide a basis for the growth of employment in tourism and landscape management.

- In terms of the sixth thematic objective - the promotion of efficiency in environmental protection and resource utilisation -, Hungary's world heritage sites are also resources to be protected and developed. The protection, demonstration and utilisation of national parks, certified health resorts and various built secular and ecclesiastical heritage sites represent an essential improvement potential. Familiarity with and visits to heritage sites can be increased by organising them into a network. Cultural values can be found at most settlements in Hungary and their preservation and utilisation can be linked to both urban and rural developments.

- The seventh thematic objective, i.e. promoting sustainable transportation and removing bottlenecks from the main network infrastructure, includes the development of the Danube corridor, and is of special importance due to navigability, tourism and drinking water, making it a priority area also at a macro-regional level.

- The fulfilment of the eighth thematic objective. i.e. supporting sustainable and high-quality employment and worker mobility, primarily requires means to boost economic development: firstly, to strengthen the employment capacity of the SME sector; secondly, to develop labour-intensive economic segments, and thirdly, to build the economy with focus on social needs. The farm coach service programme and other rural tourism development projects have had significant employment impacts on rural development.

In certain operational programmes, the thematic areas eligible for grants from different funds or programmes are identified as thematic areas with particular integration needs. Tourism is such a thematic area, as the different grants that may be granted to it have distinct beneficiaries, policies, methodologies, aims, geographical scopes, supportable activities and project sizes or different dates. As a result, the utilisation, monitoring and evaluation of grants requires careful professional coordination. The following are the support programmes and funds available for tourism development as an area with special integration needs:

- Financing improvement in the Hungarian Fisheries Operational Programme by the European Maritime and Fisheries in the framework of co-financing. The programme supports the diversification of activities of aquaculture enterprises through developing other activities, like transport and fishing tourism. The Economic Development and Innovation Operational Programme supports larger, while the European Agricultural Fund for Rural Development advocates smaller tourism investments.

- The first priority axis of the Territorial and Settlement Development Operational Programme is aimed at the development of the regional economic environment in order to promote employment. The programme links up the achievement of the sixth and the eighth thematic objectives. The essence of a socially and environmentally sustainable tourism development measure is the utilisation and development of local cultural, built and natural heritage sites of regional significance and representing 
tourism attractions, with the aim of creating jobs. The grant can be used for local ecotourism development, the utilisation of cultural attractions and the development of cycle tracks for tourism.

- As the Rural Development Programme is included in the Common Agricultural Policy, special institutional rules apply. Within the framework of the diversification of agricultural enterprises, tourism can be developed from non-refundable sources. The preservation, maintenance and transmission of the cultural and built heritage and the natural values of rural areas are the engine of the operation of rural communities.

- One of the most important objectives of the Economic Development and Innovation Operational Programme is to increase the employment rate in Hungary. On the one hand, this requires the creation of new jobs, and on the other, there is a need to improve the skills of workers. Further two important objectives of the programme are the focused development of Hungary's innovation capabilities and capacities and of its industry and service sectors. The development of priority attractions based on the heritage development of the programme is realized in connection with thematic objective 6 . The support of tourism destination management organisations and tourism marketing and communication activities means one form of enterprise supports under the third thematic objective.

The Economic Development and Innovation Operational Programme supports seven different thematic objectives, covering the areas of Research and Development $(\mathrm{R}+\mathrm{D})$, Information Communication Technology (ICT), Small and Medium-Sized Enterprises (SME), the economy with low carbon-dioxide emission, tourism, employment, training and adult and vocational education. The Economic Development and Innovation Operational Programme is supported from Structural Funds, including the European Regional Development Fund and the European Social Fund (Table 2).

Table 2: Distribution of the Operational Programme resources between priority axes

\begin{tabular}{l|l|c|c|c}
\hline \multicolumn{1}{c|}{ Priority } & \multicolumn{1}{|c|}{ Name } & $\begin{array}{c}\text { Thematic } \\
\text { objective }\end{array}$ & $\begin{array}{c}\text { Ratio of } \\
\text { resources } \\
\mathbf{\%}\end{array}$ & Resource, EUR \\
\hline GINOP 1. & SME & 3 & 18.05 & $1,581,970,695$ \\
\hline GINOP 2. & $\begin{array}{l}\text { Research and technology } \\
\text { development and innovation }\end{array}$ & 1 & 19.26 & $1,687,617,126$ \\
\hline GINOP 3. & ICT & 2 & 5.19 & $454,794,075$ \\
\hline GINOP 4. & Energy & 4 & 2.57 & $225,555,211$ \\
\hline GINOP 5. & Employment & 8 & 18.97 & $1,662,839,216$ \\
\hline GINOP 6. & Competitive workforce & 10 & 4.99 & $437,236,313$ \\
\hline GINOP 7. & Tourism & 6 & 4.11 & $360,532,093$ \\
\hline GINOP 8. & Financial tools & $1,2,3,4,8$ & 26.86 & $2,352,885,426$ \\
\hline Total & & $\mathbf{1 0 0}$ & $\mathbf{8 , 7 6 3 , 4 3 0 , 1 5 5}$ \\
\hline
\end{tabular}

Source: Based on the Economic Development and Innovation Operational Programme 
The seventh priority axis: tourism can be linked to the sixth thematic objective, i.e. the protection and preservation of the environment and the promotion of efficiency in resource utilisation, under the EU2020 aims. In the middle of the priority axis, the protection of cultural and natural resources and the increase of the economic utility can be found.

Areas covered by the seventh priority of the operational programme:

- Network development of cultural and natural heritage sites of national and international importance.

- Development of attractions of international importance which can reach new target groups and can reduce the territorial concentration of tourism.

- The experience-oriented presentation of natural values as tourism attractions is performed with consideration to the load-bearing capacity of the area.

- It is essential to create an independent image, an environment of international standard and supply of the destination at health resorts.

Indicators of the expected outcome:

- Increase in spending by domestic and international tourists from HUF 1,153,109 million (2013) to HUF 1,268,000 million (to 2023) in the less developed region.

- Increase in the expected number of visits at natural and cultural heritage sites and in supported attractions from 352,000 (2013) to 1,660,000 visits/year (to 2023).

\section{CLASSIFICATION OF GRANTS, AND THE AGGOUNTING OF ECONOMIC EVENTS}

In Hungary, grants can be classified in many ways (Chart 5), however, in order to explain their accounting, one needs to understand the principle of comparison. According to Section 15 (7) of the Accounting Act, "When defining the profit or loss for a certain period of time, the recognized revenues of the performance in the period concerned of the activities and costs (expenditures) corresponding to such revenues must be taken into account, regardless of their financial settlement" (Act C of 2000 on Accounting).

For accounting, the classification based on the objectives of the grants is relevant because non-refundable grants received for offsetting costs (expenses), non-refundable grants for development objectives and grants to be placed in the capital reserve are recognised differently. The grants received for operating purposes are either support granted for activities not profitable under market conditions or for outsourcing state and local government tasks. Table 3 shows the accounting of grants received for operating purposes.

One of the major problems encountered by accounting experts in recent years has been that costs and expenses were regularly incurred, while successful tenders are typically paid only after completion. Consequently, revenues and expenses are accounted in different financial years. However, the amendment of the Accounting Act reconciled the regulations with the principle of comparability. In the case of post-financing the amount of unpaid grants can also be accrued and deferred against other revenues 


\section{Chart 5: Classification of grants}

\section{According to the purpose of the grant}

- for operational objective

- development grant

- grant in the form of capital reserves

Based on the financing method

- pre-financing

- post-financing

According to the form of the grant

- paid in cash (in one sum, paid in installments)

- received in the form of an asset

- receivable forgiven

\section{According to the form of financing the grant}

- refundable

- non-refundable

Source: Authors' own

Table 3: The accounting of grants granted for activities

\begin{tabular}{l|l|l}
\hline \multicolumn{1}{c|}{ Economic event } & \multicolumn{1}{c|}{ Debit account } & \multicolumn{1}{c}{ Credit account } \\
\hline Advance on the grant or grant & Liquid assets & Short-term liabilities \\
\hline Advance transfer & Short-term liabilities & Other revenues \\
\hline $\begin{array}{l}\text { Grants received up to the balance sheet date } \\
\text { during the reporting year }\end{array}$ & Liquid assets & Other revenues \\
\hline $\begin{array}{l}\text { Repayment of grants received in the report- } \\
\text { ing year }\end{array}$ & Other revenues & Liquid assets \\
\hline $\begin{array}{l}\text { Repayment of grants received in years pre- } \\
\text { ceding the reporting year }\end{array}$ & Other expenses & Liquid assets \\
\hline $\begin{array}{l}\text { Grants received up to the balance sheet date } \\
\text { in the reporting year }\end{array}$ & $\begin{array}{l}\text { Accruals and deferred } \\
\text { income }\end{array}$ & Other revenues \\
\hline $\begin{array}{l}\text { The beneficiary fulfils the conditions and } \\
\text { will be granted the grant }\end{array}$ & $\begin{array}{l}\text { Accruals and deferred } \\
\text { income }\end{array}$ & Other revenues \\
\hline
\end{tabular}

Source: Authors' own

if the entrepreneur is able to prove that it will be able to fulfil the conditions related to grants and it is expected to get the grant. In this case, the entrepreneur must prove that the conditions for accruals and the obligations undertaken in the grant contract have been fully met.

Grants received for development purposes promote long-term business development. In Hungary, post-financing is characteristic in the case of grants received from 
public or other sources. In the case of non-refundable grants granted for development purposes, the principle of comparability is ensured, since revenues can be accounted at the same time as cash flow, which can be deferred as revenue. Deferral is derecognised when the expense is recognised (Table 4).

Table 4: Accounting grants received for development

\begin{tabular}{l|l|l}
\hline \multicolumn{1}{c|}{ Economic event } & \multicolumn{1}{c|}{ Debit account } & \multicolumn{1}{c}{ Credit account } \\
\hline Grant received for development & Liquid assets & Other revenues \\
\hline Deferral of grant & Other revenues & $\begin{array}{l}\text { Accrued expenses } \\
\text { and deferred income }\end{array}$ \\
\hline Advance on grant for development & Liquid assets & Short-term liabilities \\
\hline $\begin{array}{l}\text { Reversal of proportional part on approval } \\
\text { of settlement }\end{array}$ & Short-term liabilities & Other revenues \\
\hline Release of deferral & Passive accruals & Other revenues \\
\hline $\begin{array}{l}\text { Repayment of grants received in the current } \\
\text { year }\end{array}$ & Other revenues & Liquid assets \\
\hline $\begin{array}{l}\text { Repayment of grants received in the years } \\
\text { preceding this reporting year }\end{array}$ & Other expenses & Liquid assets \\
\hline
\end{tabular}

Source: Own editing

Support granted to the credit of capital reserves affect a relatively narrow circle. Grants received from public appropriations can be recognised in the capital reserve if this is what the grant contract expressly stipulates. These grants must be accounted as equity in the capital reserve simultaneously with the cash flow, and a reserve must be set aside at the time of accounting. These grants cannot be recognised as income. Disbursement of the grant is conditional, the committed reserve must be terminated at the pace and rate the grant is implemented. Grant accounting is detailed in Table 5.

Table 5: Accounting grants in the capital reserve

\begin{tabular}{l|l|l|}
\hline \multicolumn{1}{|c|}{ Economic event } & \multicolumn{1}{c|}{ Debit account } & \multicolumn{1}{c|}{ Credit account } \\
\hline $\begin{array}{l}\text { Grant received for development and to be } \\
\text { recognised in the capital reserve }\end{array}$ & Liquid assets & Capital reserve \\
\hline $\begin{array}{l}\text { Transfer of a conditional grant to the com- } \\
\text { mitted reserve }\end{array}$ & Capital reserve & Committed reserve \\
\hline $\begin{array}{l}\text { Release of the committed reserve on meeting } \\
\text { the conditions }\end{array}$ & Committed reserve & Capital reserve \\
\hline $\begin{array}{l}\text { Reversal of a grant repayable in thie } \\
\text { reporting year }\end{array}$ & Committed reserve & Capital reserve \\
\hline Repaid development grant & Capital reserve & Liquid assets \\
\hline
\end{tabular}

Source: Authors'own 


\section{The Administrative Procedures of Grants}

For the purposes of the analysed topic, the grant procedure is divided into four main phases. These phases may be managed by separate departments or other organisational units of the enterprise, or by a contracted agency, entrepreneur or other external organisation. They may include official monitoring and authorisation procedures in relation to putting the investment into operation. Chart 6 shows the procedure of tender project management.

\section{Chart 6: Procedures in tender project management}

\begin{tabular}{|c|c|c|c|}
\hline $\begin{array}{l}\text { Call for } \\
\text { tenders } \\
\text { Clarification } \\
\text { Filling in the } \\
\text { application } \\
\text { form } \\
\text { Submission } \\
\text { Verification } \\
\text { Grant contract }\end{array}$ & $\begin{array}{l}\text { Asking for a quote } \\
\text { Contracting for } \\
\text { implementation } \\
\text { Bondgeting } \\
\text { B. Implementation } \\
\text { Up-to-date } \\
\text { recording and } \\
\text { accounting of } \\
\text { documents }\end{array}$ & $\begin{array}{l}\text { Account blocking } \\
\text { Compiling documents } \\
\text { Preparation of financial } \\
\text { statements } \\
\text { Submission/uploading } \\
\end{array}$ & 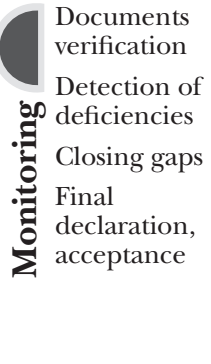 \\
\hline
\end{tabular}

Source: Authors'own

Initially, as step zero, support options should be discovered. In case we opt for a tender, a tender project management is performed.

1. Application: The call for applications must be thoroughly reviewed, each criterion should be considered, making sure that it can be fulfilled within the applicant's capabilities. When the project has been clarified, the application form is filled in, and the application is finalised. As a next step, the board verifies the content of the tender and in most cases there is a possibility to fill in the gaps. If these tasks have been successfully completed, the grant board evaluate and score the application, and if they find everything satisfactory, they approve it. The grant contract is signed after the application and before implementation. In the case of EU funds, the contract is concluded between the managing authority and the applicant, while in the case of national funding, between the granting authority and the applicant.

2. Implementation and project management: The majority of tender invitations require documentation of this phase, specifying form and content. In this phase particular attention must be paid to the requirements set out in the grant contract concerning financial processes. If the project is pre-financed, the collection of the grant amounts must be monitored according to the grant contract. The expected incomes and revenues are reasonably calculated and a financial schedule is compiled to trace and update progress. It is especially important to monitor and verify the compliance of offer requests, orders and the preparation of contracts with suppliers and contractors. The form and content of invoices, certificates of performance, official reports, 
and notes issued during implementation should be correct and in compliance with the contract. They should include the project-related data that allow the clarification of the identity. It is necessary to manage the documentary evidence according to the classification of project elements or in a breakdown by cost groups, and to manage accounts based on the budget of the project and the possible reclassification, and to track booking of the submitted documents. It is an important controlling task to recognise the need for change and modification of frames determined in the budget in time, and to work out a proposal for modification.

3. Accounting phase: In order to support resource utilisation, in this phase a proper accounting and report must be prepared and submitted to the competent or monitoring organisations and to the sponsor. The form and content requirements of the report are determined by the tenderer. In the course of accounting the grants, the summary account must be created in a way to meet both the requirements of the Accounting Act and the needs expected by the sponsor. At the same time, it must be borne in mind that the sponsor's expectations cannot overwrite regulatory requirements. The report may be compiled and submitted via an electronic interface (e.g. in the case of EU financing, the Unified Monitoring Information System, and in case of national financing, the Electronic Tender and Cooperation System) provided by the sponsor, but at the same time a paper-based submission is almost always required, which may include electronic documentation (CD, pen-drive). The submitted invoices must fulfil the formal and content requirements of the grant contract and must be accompanied by the relevant documents (bank statements, ledger statements, payrolls etc.). Most tenders have special rules and many grants involve complicated, overregulated and over-documented accounting.

4. Assessment phase: Most frequently, an external Intermediate Body, Managing Authority or a Certifying Authority carries out monitoring with the aim to ensure genuineness of the costs reported to the European Commission or to the State, and their compliance with the rules and principles. For the purpose of monitoring, the National Development Agency has published the Interactive Operation Manual, which regulates the monitoring procedure. This first-level procedure based on an itemised verification can (at the very best) justify that the payment claims of the beneficiary are correct, the accounted costs have really been incurred and are satisfactorily supported by accounting and other documents, and meet the formal and content requirements and the objectives and indicators set out in the relevant grant contract. The secondlevel monitoring may be an on-site audit of the cooperating institution, by the Hungarian Treasury and the Directorate-General for European Aid Audit. The next step can be the final monitoring, carried out before the closure of the operational programme. At this point it is also possible to fill in gaps, and then if everything is found correct, during monitoring, the next steps are the approval of the accounting and the issue of the final or closing declaration.

5. The final phase is project maintenance can be regarded as the closing section, since the Council of the European Union regulates that the projects financed from the European Regional Development Fund (ERDF), European Social Fund (ESF) 
and the Cohesion Fund must be maintained for five, but minimum three years, under the pain of grant repayment, and the beneficiary may be obliged to submit annual project maintenance reports.

\section{SUMMARY}

Tourism is one of the most significant sectors and a priority area in the Hungarian development policy. In the EU programming period 2014-2020, tourism development projects can be accomplished in the frame of several operational programmes. EU funs provide possibilities for interactive and experience-oriented projects for visitor centres and nature trails. Grants are available for the renewal of one hundred thousand hectares of habitat, livestock housing and nature conservation site guarding services. Non-refundable grants can be requested for complex tourism development projects in national parks, for attraction improvement and for improvement in conditions of hosting, which can considerably increase the number of visitors. The maintenance of cultural and natural values can be achieved by developing tourism supply based on presenting heritage sites and by increasing tourism revenues.

A large number of grants are widely available in adjustment to topical matters and subject to increasingly specific and accurate legal conditions, while the regulatory and control system is increasingly stricter and more comprehensive. The objectives of the Structural Funds established by the European Union are to improve competitiveness, social and economic cohesion, innovation and information and communication technologies, raise the standards of employment and education, and emphasise the significance of reducing inequality and of sustainable growth. The budget offers the greatest amounts to projects aimed at achieving these goals, while also allowing for environment-friendly options. With a view to these values, in the current programming period eleven thematic objectives have been set in Hungary on the basis of the operational programmes adopted by the European Commission.

In terms of accounting, the recognition of three underlying economic events has been overviewed in this paper. In the case of non-refundable grants for costs and expenses, the cost and expenses incurred and accounted by enterprise reduce the profit, and the amount of the grant can be recognised as other income, not only as in the cash flow account but also if the entrepreneur can prove that he will fulfil the conditions of the grant and it is likely to be granted the support, and thus the principle of comparison is met. In the case of grants received for development objectives, only the amounts actually received can be shown as other revenue. In case of these grants, a problem may arise when the advance granted for the tender is accounted, as until it is finalised, it must be recognised among short-term liabilities. After approval of the accounting of a given implementation stage, the proportional part of the grant must be transferred from short-term liabilities to other revenues. Within the frame of development tenders, enterprises typically generate assets or intangible assets, and the deferred income can be reversed by depreciation. Grants received to the credit of the capital reserve are accounted simultaneously with cash flows and must be transferred 
from the capital reserve to the fixed reserve because these amounts must be repaid if the conditions of the contract are not fulfilled. Contracts specify a monitoring period and when it expires, the fixed reserve can be released and the amount must be reversed to the capital reserve.

In our opinion, there are many opportunities for using grants and they give an opportunity for innovative projects to promote the development of tourism and for reducing the gap. The long-term effects of using grants must be kept in mind as the investment resources included in such grants provide significant financial advantage, but the additional and maintenance costs that are incurred in relation to these investment or development projects must also be considered.

\section{REFERENCES}

Act C of 2000 on Accounting. https:/ /net.jogtar.hu/jogszabaly?docid=A0000100.tv\&dbnum=62\&getdoc=1. Gazdaságfejlesztési és Innovációs Operatív Program [Economic Development and Innovation Operational Programme], www.palyazat.gov.hu/doc/4380.

Lengyel, M. (2004): A turizmus általános elmélete [General theory of tourism]. Heller Farkas Gazdasági és Turisztikai Szolgáltatások Fốiskolája, Budapest.

Pannon University (2008): Országos ökoturizmus-fejlesztési stratégia [National tourism development strategy]. Pannon University, Aquaprofit Zrt., Veszprém, Budapest.

The Partnership Agreement for Hungary, 2014-2020, www.palyazat.gov.hu/program_szechenyi_2020. 